\title{
ANALISIS KOEFISIEN PENGURANGAN TATAL (CHIP REDUCTION COEFFICIENT) PADA PEMESINAN BUBUT MAGNESIUM AZ31 MENGGUNAKAN PAHAT PUTAR
}

\author{
Gusri Akhyar Ibrahim \\ Teknik Mesin \\ Universitas Lampung \\ Email: gusri.akhyar@eng.unila.ac.id \\ Arinal Hamni \\ Teknik Mesin \\ Universitas Lampung \\ Email: arinal.hamni@eng.unila.ac.id \\ Rofika Libiru \\ Teknik Mesin \\ Universitas Lampung \\ Email: rofika.libiru@stud.unila.ac.id
}

\begin{abstract}
ABSTRAK
Coefficient reduction chip atau pengurangan tatap dianalisa menggunakan Metode Anova untuk menentukan pengaruh dari parameter input untuk setiap variasi eksperimen pada proses permesinan, sekaligus juga menentukan persentase pengaruh parameter individual. Metode Taguchi dipilih untuk mengurangi jumlah total dari percobaan yang dilakukan dan menghilangkan aspek yang tidak perlu dipertahankan, mengurangi biaya percobaan, sederhana dan mendapatkan hasil yang presisi. Penelitian ini bertujuan untuk menganalisa koefisien pengurangan tatal yang terjadi pada saat pemesinan menggunakan material paduan magnesium AZ3. Pada penelitian ini, proses pemesinan dilakukan menggunakan mesin bubut dengan jenis pahat berputar, yang mana pahat yang digunakan adalah pahat karbida jenis round insert. Sementara itu metode pengujian yang diterapkan adalah menggunakan Metode Taguchi dan ANOVA. Sementara itu, diameter benda kerja digunakan sebesar $35 \mathrm{~mm}$ dan Panjang $100 \mathrm{~mm}$, kedalaman potong $1 \mathrm{~mm}$ dan kecepatan potong 80, 120, 160 $\mathrm{mm} / \mathrm{min}$, kadar pemakanan $0,100,150,20 \mathrm{~mm} / \mathrm{rev}$, kecepatan putaran pahat 50, 80, $120 \mathrm{rpm}$. Hasil dari penelitian ini menunjukan bahwan nilai koefisian pengurangan tatal terendah sebesar adalah 1,44 , yang mana diperoleh pada parameter kecepatan potong $80 \mathrm{~mm} / \mathrm{min}$, kedalaman potong $1 \mathrm{~mm}$, kadar pemakanan $0,10 \mathrm{~mm} / \mathrm{rev}$ dan kecepatan putaran pahat $50 \mathrm{rpm}$. Dari semua faktor yang dianalisa, didapati bahwa faktor yang berpengaruh signifikan yaitu kecepatan potong da kadar pemakanan.
\end{abstract}

Kata kunci: koefisien tatal, taguchi, pemesinan bubut, magnesium

\begin{abstract}
Coefficient reduction chip was analyzed by using Analysis Varian Method to define the effect of input parameters on all of experimented responses and also to define individual percentage of each parameter. Taguchi Method was implemented to decrease the amount of experiment numbers, and deprive unnecessary aspect, to reduce the cost, simply and precisely. This experiment aims to analyze the coefficient reduction of chip during machining of magnesium AZ31. The machining process took place by using Lathe machine with rotary cutting tool, in which, the material of cutting tool is carbide round insert. In this experiment, the dimension of workpiece are diameter of $35 \mathrm{~mm}$
\end{abstract}


and length of $100 \mathrm{~mm}$, depth of cut of $1 \mathrm{~mm}$. And then the cutting speed of 80,120,160 mm/min, feed rate of $0,10,0,15,0,20 \mathrm{~mm} / \mathrm{rev}$, and speed of rotary tool of 50,80,120 rpm. The results of the experiment show that the lowest value of coefficient reduction chip is 1,44, in which is reached at machining parameter cutting speed of by $80 \mathrm{~mm} / \mathrm{min}$, depth of cut of $1 \mathrm{~mm}$, feed rate of $0,10 \mathrm{~mm} / \mathrm{rev}$ and speed of rotary tool of $50 \mathrm{rpm}$. The factor that gave significant contribution are cutting speed and feed rate.

Keywords: chip reduction coefficient, taguchi, lathe machining, magnesium

\section{PENDAHULUAN}

Material magnesium AZ31 merupakan salah satu contoh paduan magnesium dengan alumunium dan zinc dimana persentase dari masing-masing paduan adalah sekitar $9 \%$ dan $1 \%$. Magnesium merupakan elemen terbanyak kedelapan yang membentuk $2 \%$ berat kulit bumi, serta merupakan unsur terlarut ketiga terbanyak pada air laut. Di dalam unsur kimia pada tabel periodik magnesium memiliki simbol Mg dan memiliki nomor atom 12 serta berat atom 24,31. Magnesium dan paduannya telah digunakan secara luas dalam industri otomotif, karna bobotnya yang ringan dapat mengurangi berat dari komponen yang akan dibuat. Kelebihan lain dari magnesium yaitu memiliki mechanical properties yang sangat baik, kemampuan pemesinan yang baik, memiliki tingkatan kadar elektromagnetis yang baik, stabilitas dimensi yang tinggi, memiliki power to weight ratio yang tinggi, dan kemampuan menahan korosi yang baik [1]. Dengan berbagai kelebihan dari magnesium dan ketersediaan jumlahnya yang melimpah di alam, maka pengembangan magnesium sebagai bahan baku alternatif besi/baja sangatlah menjanjikan.

Walaupun magnesium memeiliki banyak kelebihan, namun, magnesium juga memiliki beberapa kelemahan sehingga mendapatkan kendala Ketika memilih magnesium sebagai bahan baku. Salah satu kelemahannya yaitu kekuatan tariknya rendah sehingga harus dipadu dengan bahan logam lain. Magnesium biasanya dipadu dengan bahan alumunium dan seng untuk menaikkan kekuatan tariknya, magnesium paduan yang sangat elastis dan banyak digunakan saat ini adalah magnesium AZ31 [2]. Kelemahan lain dari magnesium yaitu mudah sekali terbakar ketika dimesin karena titik nyalanya yang rendah, magnesium dapat terbakar ketika temperatur pemotongan melewati titik leleh material yaitu pada $400^{\circ} \mathrm{C}-600^{\circ} \mathrm{C}$. Faktor utama digunakannya magnesium, karena mechanical property-nya yang sangat mirip dengan tulang asli dan mampu mengurangi fenomena stress pada tulang, serta dapat luruh di dalam tubuh [3]. Dalam bidang biomedic komponen ulir merupakan komponen yang sangat penting pada proses implantasi tulang. Hal inilah yang menunjukkan bahwa pengembangan magnesium sebagai bahan material untuk komponen ulir biomedic sangat menjanjikan, tetapi untuk mendapatkan kwalitas ulir magnesium yang baik harus dilakukan pemilihan parameter pemotongan yang tepat [4].

Proses bubut adalah proses pemesinan untuk menghasilkan komponen mesin berbentuk silindris yang dikerjakan dengan menggunakan mesin bubut. Prinsip dasarnya dapat didefinisikan sebagai proses pemesinan permukaan luar benda silindris atau bubut rata Tiga parameter utama pada setiap proses bubut adalah kecepatan putar spindle (speed), gerak makan (feed) dan kedalaman potong (depth of cut). Faktor yang lain seperti bahan benda kerja dan jenis pahat sebenarnya juga memiliki pengaruh yang cukup besar, tetapi tiga parameter di atas adalah bagian yang bisa diatur oleh operator langsung pada mesin bubut [5].

Metode untuk menurunkan suhu pemotongan dan untuk meningkatkan produktivitas pemesinan yaitu dengan menggunakan pahat potong berputar. Pada mekanisme pahat putar, dimana pahat potong yang berputar maka mata pahat (cutting edge) akan didinginkan selama periode tanpa pemotongan (non-cutting period) dalam satu putaran pahat potong [6]. Hal ini diharapkan bahwa suhu pahat potong akan menurun dibandingkan dengan proses pemesinan bubut konvensional (pahat potong diam). Selain itu proses pemesinan dengan pahat berputar ini dimungkinkan dapat digunakan untuk pemotongan kecepatan tinggi (high speed cutting) untuk material Magnesium (Magnesium Alloy) dan material yang sulit dipotong (difficult to-cut materials) seperti paduan Nikel (Nickel Alloy), Titanium (Titanium Alloy). Dalam penelitian Harun menyebutkan bahwa hasil pengukuran 
komponen gaya pada pemesinan bubut dengan sistem pahat berputar menggunakan force ring dynamometer menunjukkan bahwa dinamometer ini sensitif terhadap gaya pemotongan di bawah perubahan kondisi pemesinan meliputi kecepatan potong, kecepatan putar pahat dan depth of cut [7].

Dalam penelitian Anurag jika nilai $(\xi)$ lebih dari kekuatan dan energi yang dibutuhkan untuk memotong material. Sangat penting untuk mengurangi nilai $(\xi)$ tanpa mengurangi produktivitas. Jadi koefisien pengurangan tatal adalah aspek machinability yang sangat penting di area permesinan. Dari plot efek utama untuk $(\xi)$ bahwa kecepatan potong dan kadar pemakanan berbanding terbalik dengan koefisien pengurangan tatal. Dengan pengingkatan kecepatan potong dan kadar pemakanan koefisien reduksi chip menurun. Dengan mempertimbangkan kedalaman potong semua nilai $(\xi)$ terletak pada rata-rata. Jadi kedelaman potong tidak banyak berpengaruh pada koefisien pengurangan tatal [8]. Metode Taguchi merupakan metode yang rekomendasikan untuk memperbaiki kualitas produk dan proses serta dapat menekan biaya seminimal mungkin. Faktor faktor dibagi berdasarkan level, kemudian memilih matriks orthogonal untuk memudahkan pelaksanaan ekperimen. Hasil ekperimen dianalisis dengan Signal to Noise Ratio (S/N) dan ANOVA untuk menentukan faktor-faktor dan level faktor yang paling berpengaruh [9].

Dari penelitian yang sudah dilakukan maka untuk mendapatkan nilai koefisien reduksi tatal yang baik untuk menghasilkan produk yang lebih bagus digunakan metode yang berbeda. Uraianuraian tentang penelitian terdahulu di atas yang menjadi acuan penulis dalam mengangkat topik analisis koefisien pengurangan tatal (chip reduction coefficient) pada pemesinan bubut Magnesium AZ31 rotary tool. Penelitian ini bertujuan menganalisis varian untuk mendapatkan pengaruh variasi parameter pemotongan terhadap koefisien pengurangan tatal menggunakan Metode Taguchi dan analisis varian (Anova).

\section{METODOLOGI PENELITIAN}

Penelitian dilakukan menggunakan mesin bubut konvensional dengan mata pahat insert carbide (Gambar 1) dan menggunakan jenis sistem pahat berputar (Gambar 2a). Penelitian menggunakan material magnesium AZ31 (Gambar 2b) dengan design of experiment yaitu Metode Taguchi L9, dimana variasi kecepatan potong sebesar $80,120,160 \mathrm{~mm} / \mathrm{min}$, kedalaman potong 1 $\mathrm{mm}$, kadar pemakanan sebesar 0,10, 0,15, 0,20 mm/rev dan kecepatan putaran pahat sebesar 50, 80, $120 \mathrm{rpm}$. Respon pengamatannya yang diperhatikan adalah tebal tatal dan lebar tatal.
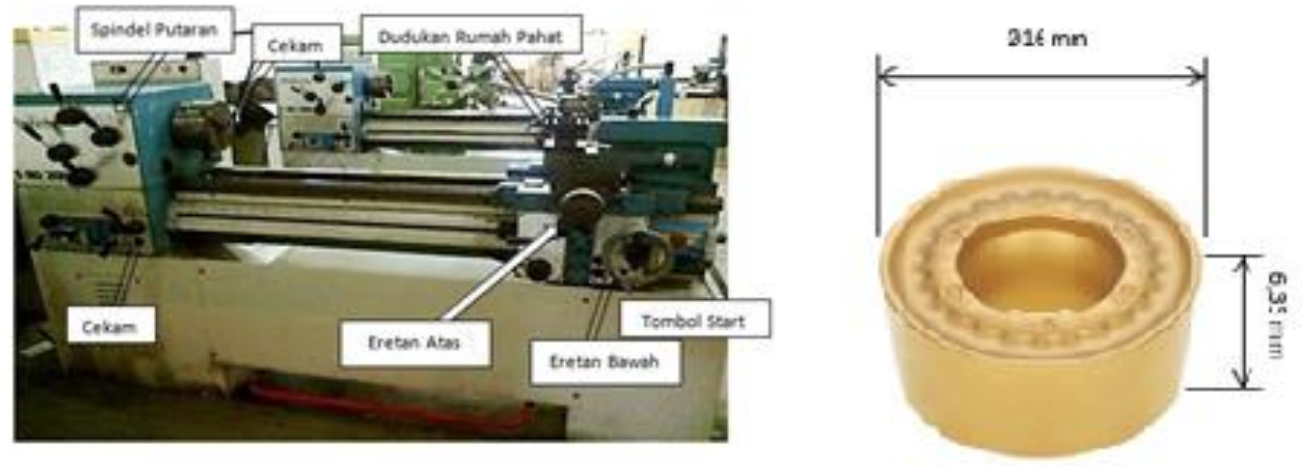

Gambar 1. (a) Mesin Bubut yang Digunakan dan (b) Pahat Potong Jenis Insert Rotary Carbide 


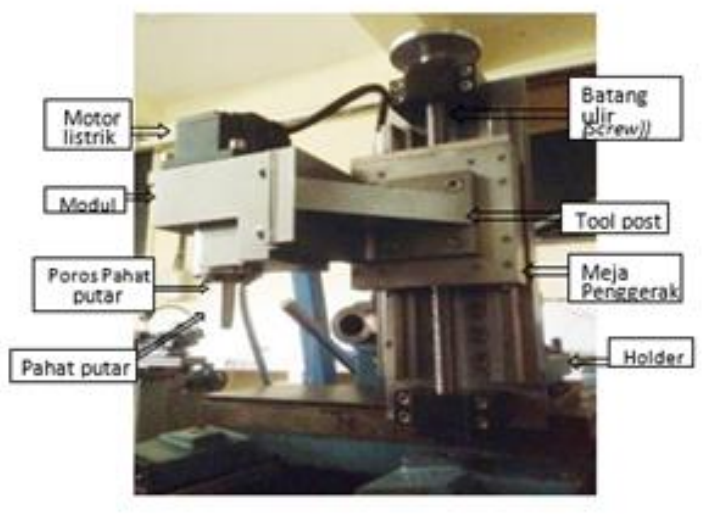

(a)
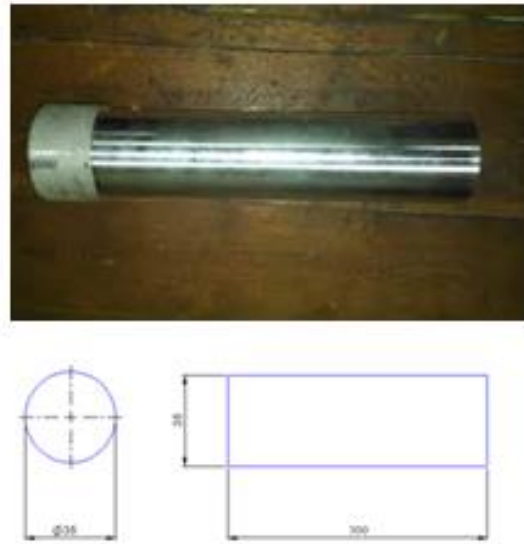

(b)

Gambar 2. (a) Sistem Pahat Putar dan (b) Material Magnesium yang Digunakan

Tabel 1. Orthogonal Array L9

\begin{tabular}{ccccc}
\hline No & $\begin{array}{c}\text { Kedalaman } \\
\text { Pemotongan } \\
(\mathrm{mm})\end{array}$ & $\begin{array}{c}\text { Kecepatan } \\
\text { Benda } \\
\text { Kerja } \\
(\mathrm{m} / \mathrm{min})\end{array}$ & $\begin{array}{c}\text { Kecepatan } \\
\text { Pemakanan } \\
(\mathrm{mm} / \mathrm{rev})\end{array}$ & $\begin{array}{c}\text { Kecepatan } \\
\text { Putaran } \\
\text { Pahat } \\
(\mathrm{rpm})\end{array}$ \\
\hline 1 & 1 & 80 & 0,10 & 50 \\
2 & 1 & 80 & 0,15 & 80 \\
3 & 1 & 80 & 0,20 & 120 \\
4 & 1 & 120 & 0,10 & 80 \\
5 & 1 & 120 & 0,15 & 120 \\
6 & 1 & 120 & 0,20 & 50 \\
7 & 1 & 160 & 0,10 & 120 \\
8 & 1 & 160 & 0,15 & 50 \\
9 & 1 & 160 & 0,20 & 80 \\
\hline
\end{tabular}

Tahapan dari pengolahan data direncanakan dengan terlebih dahulu melakukan Taguchi analysis untuk mencari kombinasi optimal dari semua faktor untuk setiap respon, dengan mencari Signal Noise Ratio (SNR). SNR untuk ketiga respon tersebut sama yaitu Smaller-the-Better (STB). Rumus yang diapakai adalah :

a. Menghitung SN Ratio sesuai dengan Metode Taguchi: 
SNR STB $=-10 \log \left[X i(j)^{2}\right]$

Dimana:

$X i(j)=$ nilai eksperimen ke $-\mathrm{i}$ pada respon ke-j

b. Melakukan perhitungan chip reduction coefficient

$$
\mathrm{r}=\mathrm{to} / \mathrm{tc}
$$

Dimana:

$\mathrm{r}=$ rasio ketebalan tatal (chip thickness ratio)

to = Ketebalan tatal (depth of cut)

tc $=$ Tebal tatal (separation)

\section{HASIL DAN PEMBAHASAN}

Untuk mendapatkan hasil pengujian yang baik menggunakan Metode Taguchi maka dipilih jumlah sampel yang diuji adalah sebanyak 9 pengujian mengikuti susunan ortoganl L9 (Ortogonal Array (9). Data pengamatannya di optimasi menggunakan Metode Taguchi dan Anova dengan bantuan aplikasi Minitab 17 dengan cara memasukkan jumlah faktor masing-masing dan levelnya. Dengan memilih kriteria karakteristik yang digunakan yaitu semakin kecil semakin baik maka secara otomatis didapatkan rancangan yang terbaik berdasarkan analisis Taguchi.Tabel 2 merupakan data hasil pengukuran terhadap tatal yang dihasilkan untuk masing-masing kombinasi parameter pemotongan. Data diambil beberapa kali, kemudian diambil nilai rata-rata agar diperoleh tingkat kevalidan data yang tinggi. Sementara itu juga dipaparkan data lebar tatal yang diukur menggunakan alat ukur mikro meter.

Tabel 2. Data Hasil Pengukuran untuk Tebal dan Lebar Tatal

\begin{tabular}{ccccccccc}
\hline & \multicolumn{2}{c}{ Tebal (mm) } & Rata- & \multicolumn{3}{c}{ Lebar (mm) } & Rata- \\
No & $\mathbf{1}$ & $\mathbf{2}$ & $\mathbf{3}$ & rata & $\mathbf{1}$ & $\mathbf{2}$ & $\mathbf{3}$ & rata \\
\hline 1 & 0,79 & 0,79 & 0,79 & 0,79 & 1,140 & 1,140 & 1,143 & 1,141 \\
2 & 0,76 & 0,76 & 0,77 & 0,76 & 1.098 & 1.099 & 1.097 & 1,098 \\
3 & 0,75 & 0,75 & 0,75 & 0,75 & 1,095 & 1,095 & 1,095 & 1,095 \\
4 & 0,74 & 0,75 & 0,73 & 0,74 & 1,082 & 1,084 & 1,082 & 1,083 \\
5 & 0,73 & 0,74 & 0,72 & 0,73 & 1,073 & 1,074 & 1,075 & 1,074 \\
6 & 0,72 & 0,69 & 0,72 & 0,71 & 1,072 & 1,072 & 1,073 & 1,072 \\
7 & 0,69 & 0,69 & 0,69 & 0,69 & 1,052 & 1,052 & 1,054 & 1,053 \\
8 & 0,70 & 0,68 & 0,69 & 0,69 & 1,51 & 1,50 & 1,50 & 1,050 \\
9 & 0,65 & 0,66 & 0,66 & 0,66 & 1,045 & 1,045 & 1,048 & 1,046 \\
\hline
\end{tabular}


Tabel 3 menunjukan nilai hasil perhitungan koefisien pengurangan tatal, dimana dihitung menggunakan rumus 2 . Nilai ini merupakan nilai perbandingan antara tebal dan lebar tatal yang dihasilkan untuk masing-masing kombinasi proses pemotongan. Perubahan tebal dan lebar setelah dilakukan proses pemesinan adalah sebagai akibar dari terjadi perubahan bentuk atau deformasi selama proses pemsinan berlansung. Suhu yang tinggi selama proses pemotongan menyebabkan perubahan struktur pada benda kerja magnesium. Perubahan struktur tersebut tidak berbanding lurus dengan perubahan tebal tatal yang dihasilkan sehingga perbandingan antara keduanya menjadi salah satu kriteria kualitas pemesinan [9 10]

Tabel 3. Data Hasil Pengukuran Koefisien Pengurangan Tatal

\begin{tabular}{cccccc}
\hline No & $\begin{array}{c}\mathbf{d} \\
(\mathbf{m m})\end{array}$ & $\begin{array}{c}\mathbf{v c} \\
(\mathbf{m m} / \mathbf{m i n})\end{array}$ & $\begin{array}{c}\mathbf{f} \\
(\mathbf{m m} / \mathbf{r e v})\end{array}$ & $\begin{array}{c}\mathbf{v t} \\
(\mathbf{r p m})\end{array}$ & $\begin{array}{c}\text { Koefisien } \\
\text { reduksi } \\
\text { tatal }\end{array}$ \\
\hline 1 & 1 & 80 & 0,10 & 50 & 1,44 \\
2 & 1 & 80 & 0,15 & 80 & 1,45 \\
3 & 1 & 80 & 0,20 & 120 & 1,46 \\
4 & 1 & 120 & 0,10 & 80 & 1,46 \\
5 & 1 & 120 & 0,15 & 120 & 1,47 \\
6 & 1 & 120 & 0,20 & 50 & 1,50 \\
7 & 1 & 160 & 0,10 & 120 & 1,52 \\
8 & 1 & 160 & 0,15 & 80 & 1,53 \\
9 & 1 & 160 & 0,20 & 50 & 1,58 \\
\hline
\end{tabular}

Setelah diperoleh data pengujian dan data perhitungan nilai koefisien pengurangan tatal, kemudian dilakukan proses analisa menggunakan metode Varian, guna untuk mendapat pengaruh masing-masing faktor terhadap respon. Selanjutnya perhitungan dan analisa terhadap nilai signal to noise ratio juga dilakukan menggunakan Analisis Taguchi. Tabel 4 merupakan hasil analisa terhadap $\mathrm{S} / \mathrm{N}$ rasio dan Mean menggunakan Metode Taguchi pada masing-masing respon. Faktor yang diperhitungan antaranya yaitu kecepatan potong, kadar pemakanan dan kecepatan putaran pahat. Untuk perhitungan nilai koefisien pengurangan tatal ditentukan berdasarkan karakteristik smaller is Better.

Tabel 4. Respon Analysis of Variance

\begin{tabular}{|c|c|c|c|c|c|}
\hline Source & DF & Adj SS & Adj MS & $\begin{array}{c}\mathrm{F}- \\
\text { Value }\end{array}$ & $\begin{array}{c}\text { P- } \\
\text { Value }\end{array}$ \\
\hline vc & 2 & 0,009267 & 0,004633 & 34,75 & 0,028 \\
\hline$f$ & 2 & 0,010467 & 0,005233 & 39,25 & 0,025 \\
\hline vt & 2 & 0,000200 & 0,000100 & 0,75 & 0,571 \\
\hline Error & 2 & 0,000267 & 0,000133 & & \\
\hline Total & 8 & 0,020200 & & & \\
\hline
\end{tabular}

Antara faktor yang diperhitungan seperti kecepatan potong (vc), kadar pemakanan (f) dan kecepatan putaran pahat (vt), faktor kadar pemakanan $(f)$ adalah faktor yang memberikan nilai 
signifikan terbesar, karena harga P-value 0,025, dimana nilai ini lebih kecil dibandingakan dengan nilai standar sebesar 0,05 . Sementara itu, faktor kecepatan potong (vc) juga merupakan faktor yang signifikan, dimana nilai P-value 0,028, dan itu lebih kecil dibandingan dengan 0,05. Sedangkan untuk nilai faktor kecepatan putaran pahat (vt) tidak signifikan karena nilai signifikansinya lebih besar dari 0,05. Dengan demikian dapat dinyarakan bahwak faktor yang memberikan pengaruh signifikan terhadap koefisien pengurangan tatal adalah faktor kadar pemakanan dan kecepatan potong. Walau bagaimanapun, faktor kadar pemakanan adalah faktor yang paling memberikan pengengaruh signifikan dengan kontribusi paling besar [11]. Hal demikian dapat dilihat pada Tabel 5 yang memberikan informasi kalau kadar pemakan menduduki rangking ke-1 dalam memberikan pengaruh signifikan terhadap koefisien pengurangan tatal.

Tabel 5. Respon signal-to-noise ratio (s/n ratio)

\begin{tabular}{cccc}
\hline Level & vc & $\boldsymbol{f}$ & vt \\
\hline 1 & $-3,367$ & $-3,283$ & $-3,562$ \\
2 & $-3,490$ & $-3,574$ & $-3,506$ \\
3 & $-3,825$ & $-3,794$ & $-3,576$ \\
Delta & 0,458 & 0,511 & 0,070 \\
Rank & 2 & 1 & 3 \\
\hline
\end{tabular}

Gambar 5 menunjukan grafik antara masing-masing faktor terhadap nilai rasio SN koefisien pengurangan tatal pada setiap levelnya. Grafik ini juga merupakan perwujudan dari Tabel 5 yang menunjukan tingkat pengaruh masing-masing faktor. Pada Grafik dapat dinyatakan bahwan faktor kadar pemakanan (feed rate) yang menunjukan tingkat kemiringan yang paling besar, sehingga demikian faktor ini dikatakan paling memberikan pengaruh signifikan. Faktor kecepatan potong juga menunjukan pengaruh yang signifikan akan tetapi pengaruhnya lebih kecil dibandingkan dengan pengaruh faktor kadar pemakanan. Sementara itu, faktor kecepatan putaran pahat potong, sama sekali tidak memberikan pengaruh atau pengaruhnya sangat kecil. Dengan demikian dapat pula dinyatakan bahwa pengurangan dimensi tatal setelah dilakukan pemotongan sangat diterntukan oleh faktor yang menyebabkan perubahan kondisi bahan atau deformasi. Suhu adalah faktor yang memberikan kontribusi terhadap perubahan struktur bahan atau deformasi selama proses pemesinan berlansung [12]. Sementara itu, kecepatan potong adalah faktor yang berkontribusi terhadap perubahan tatap, apalagi pengaruh kecepatan potong dan kadar pemakanan memberikan pengaruh yang nyata. 


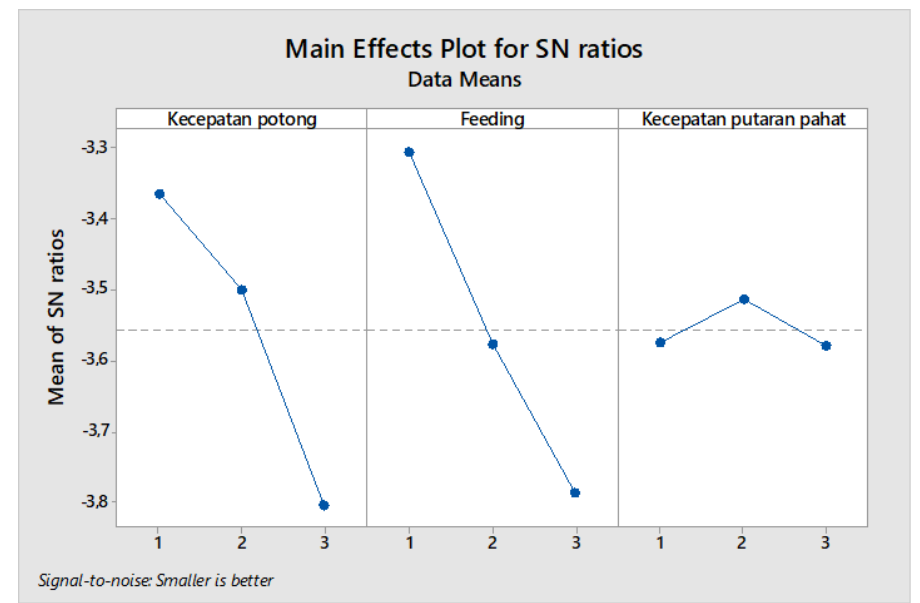

Gambar 5. Grafik Respon (S/N ratio)

Selain analisa varian terhadap nilai SN rasio atau menggunakan Metode Taguchi, juga dilakukan analisis terhadap nilai rata-rata (mean). Nilai rata-rata setiap faktor dihitung dan dianalisis sehingga didapatkan pengaruh untuk masing-masing faktor terhadap nilai mean. Tabel 6 merupakan nilai perhitungan mean untuk masing-masing faktor. Dapat diketahui bahwa parameter kadar pemakanan atau feed rate mendapatkan rank 1 yang artinya parameter ini sangat berpengaruh secara signifikan terhadap koefisien pengurangan tatal. Demikian juga dengan faktor kecepatan potong, dimana faktor ini memberikan kontribusi nyata terhadap nilai pengurangan tatal. Namun berbeda dengan faktor kecepatan putaran pahat bahwa faktor ini sama sekali tidak berkontribusi nyata. Hal ini menunjukan bahwa baik menggunakan nilai SN rasio ataupun menggunakan nilai mean, bahwa kedua-dua nilai menunjukan kalau faktor kadar pemakanan adalah faktor yang berkontribusi signifikan terhadap nilai koefisien pengurangan tatal [13]. Hal yang sama juga dapat dilihat pada Gambar 6. Kemiringan grafik pada faktor kadar pemakanan menunjukan tingkat kemiringan yang paling besar sehingga dapat dinyatakan bahwa faktor ini adalah faktor yang paling berpengaruh secara signifikan terhadap koefisien pengurangan tatal.

Tabel 6. Respon for Means

\begin{tabular}{cccc}
\hline Level & vc & $\boldsymbol{f}$ & vt \\
\hline 1 & 1,473 & 1,463 & 1,510 \\
2 & 1,497 & 1,510 & 1,500 \\
3 & 1,550 & 1,547 & 1,510 \\
Delta & 0,077 & 0,084 & 0,010 \\
Rank & 2 & 1 & 3 \\
\hline
\end{tabular}




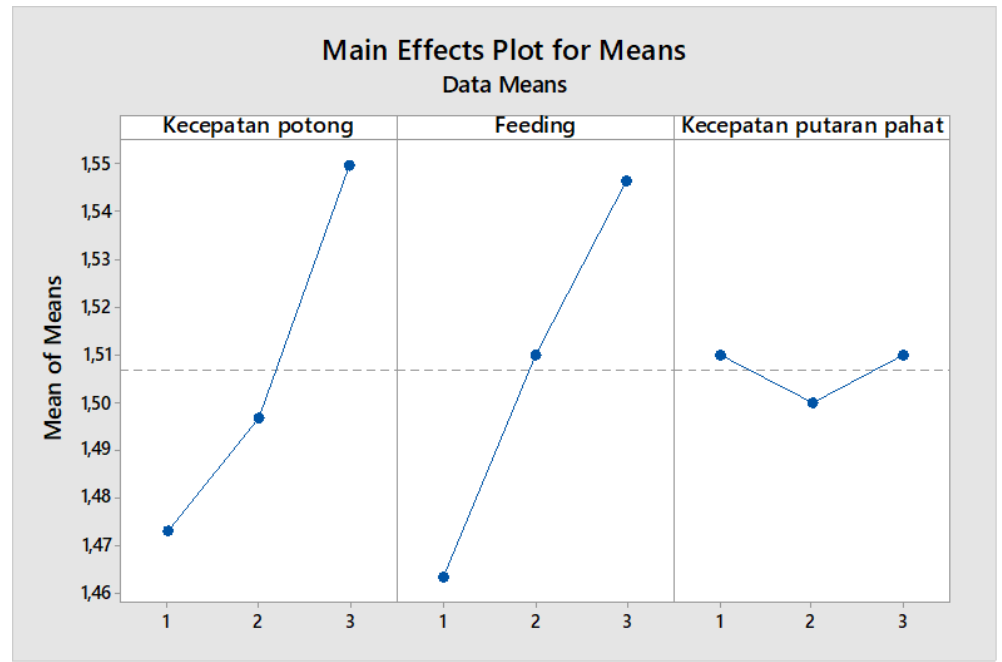

Gambar 6. Grafik Main Effect Plot for Means

Dari hasil analisis varian terhadap nilai mean dapat diketahui bahwa parameter kadar makan merupakan faktor yang menempati urutan rank yang pertama dengan nilai delta (selisih antara nilai tertinggi dengan nilai terendah) sebesar 0,084. Dimana nilai delta tersebut menyatakan bahwa pada respon for means parameter ini berpengaruh paling signifikan. Demikian juga untuk parameter kecepatan potong yang menduduki urutan rank ke 2, yang juga memberikan gambaran bahwa faktor tersebut berpengaruh lebih besar dibandingkan dengan faktor kecepatan putaran pahat. Bagaimanapun juga, karena nilai delta faktor kecepatan putaran pahat sangat kecil, maka ini menunjukan kalau faktor ini tidak memberikan pengaruh yang signifikan. Faktor kecepatan putaran pahat potong, jika dinaikan atau dikurangkan sedemikian rupa, tidaklah memberikan pengaruh yang besar terhadap perubahan nilai koefisien pengurangan tatal [12]. Dapat dinyatakan juga kalau kecepatan putaran pahat tidak menimbulkan perubahan deformasi pada struktur bahan sehingga perubahan tatal tidak banyak selama proses pemesinan berlansung.

Dari hasil analisis respon, baik menggunakan nilai $\mathrm{S} / \mathrm{N}$ ratio ataupun menggunakan nilai means, jika dibandingkan keduanya menunjukan hasil respon yaitu sama. Hasil yang sama tersebut didapatkan bahwa yang memberikan koefisien pengurangan tatap yang optimal diperoleh pada kecepatan potong dengan level 1 (sebesar $80 \mathrm{~m} / \mathrm{min})$ kadar pemakan pada level $1(0,10 \mathrm{~mm} / \mathrm{rev})$ dan kecepatan putaran pahat pada level $2(80 \mathrm{rpm})$. Untuk menghasilkan nilai koefisien pengurangan tatal yang kecil maka dapat memilih parameter pemotongan kecepatan potong yang rendah, kadar pemakanan yang rendah dan kecepatan pahat yang rendah juga. Dengan demikian dapat dikatakan untuk mengurangi perubahan struktur tatal sewaktu proses pemotongan makan pemesinan dapat dilakukan dengan cara beroperasi pada level pemilihan parameter yang rendah. Hasil analisis yang memberikan nilai koefisien pengurangan tatal yang optimal adalah sebagaimana yang ditunjukan pada Tabel 7.

Tabel 7. Respon Optimal

\begin{tabular}{llll}
\hline No & Variabel & Respon & Satuan \\
\hline 1 & vc & 80 & $\mathrm{~m} / \mathrm{min}$ \\
2 & $F$ & 0,10 & $\mathrm{~mm} / \mathrm{rev}$ \\
3 & vt & 80 & $\mathrm{Rpm}$ \\
\hline
\end{tabular}




\section{KESIMPULAN}

Dari kajian dan analisis yang dilakukan dapat disimpulkan nilai koefisien pengurangan tatal yang paling rendah sebesar 1.44, dimana diperoleh pada kondisi pemotongan kecepatan potong sebesar $80 \mathrm{~m} / \mathrm{min}$, kadar pemakanan sebesar $0,10 \mathrm{~mm} / \mathrm{rev}$ dan kecepatan putar pahat potong sebesar $50 \mathrm{rpm}$. Ada dua faktor yang memberikan pengaruh secara signifikan terhadap nilai koefisien pengurangan tatal yaitu kadar pemakanan dan kecepatan potong. Bagaimanapun juga, faktor kadar pemakanan adalah faktor yang paling signifikan pengaruhnya terhadap nilai koefisien pengurangan tatal, dimana nilai signifikannya adalah sebesar 0.025 (lebih kecil dari 0.05). Sementara itu, faktor kecepatan putar pahat potong tidak memberikan pengaruh secara signifikan baik untuk nilai respon rasio SN ataupun mean. Dari hasil analisis baik menggunakan nilai rasio SN ataupun mean bahwa kondisi pemesinan yang optimal diperoleh pada kondisi pemotongan kepatan potong (vc) sebesar $80 \mathrm{~m} / \mathrm{min}$, kadar pemakanan (f) sebesar $0,10 \mathrm{~mm} / \mathrm{rev}$ dan kecepatan pahat putar (vt) sebesar $80 \mathrm{rpm}$.

\section{UCAPAN TERIMA KASIH}

Ucapan terima kasih dan penghargaan yang sebesar-besarnya ditujukan kepada Lembaga Penelitian dan Pengabdian kepada Masyarakat Universitas Lampung yang telah memberikan kesempatan untuk mendapatkan hibah penelitian. Selanjutnya ucapan yang sama juga disampaikan kepada Jurusan Teknik Mesin Universitas Lampung yang telah memberikan kesempatan dan penggunaan fasilitas peralatan di laborarium untuk kelancaran kegiatan penelitian ini.

\section{DAFTAR PUSTAKA}

[1] L. Liwei, H. Shaohua, L. Longfei, and Y. Zhenru, Y, "High speed cutting of AZ31 magnesium alloy," Elsevier B.V. on Behalf of Chongqing University, Hunan. 2016.

[2] P. S. Sreejith, and B. K. A. Ngoi, "Dry machining of the future," Journal of Materials Processing Technology, 2000.

[3] G. A, Ibrahim, S. Harun, dan A.R. Doni, “Analisa nilai kekasaran permukaan paduan magnesium az31 yang dibubut menggunakan pahat potong berputar," Jurusan Teknik Mesin. Universitas Lampung. Bandar Lampung, 2015.

[4] D. Rahdiyanta, 2010. "Proses frais (milling), Jurusan Pendidikan Teknik Mesin Fakultas Teknik Universitas Yogyakarta, 2010.

[5] B. Buldum, S. I. K. Aydin, and O. Iskender, "Investigation of magnesium alloys machinability," International Journal of Electronics, Mechanical and Mechatronics Engineering, Vol. 3, No. 3, 361-368, 2011.

[6] S. Harun, "Cutting temperature measurement in turning with actively driven rotary tool," Key Engineering Material. Vols. 389-390, pp, 138-14, 2009.

[7] R. Anurag, R. Kumar, "Analysis of chip reduction coefficient in turning of Ti-6Al-4V ELI," School of Mechanical Engineering, Kalinga Institute of Industries Technology, Deemed to be University, Bhubaneswar-751024, 2018.

[8] H. Suryadiwansa, "Peningkatan produktivitas dan pengendalian suhu pengapian pemesinan magnesium dengan sistem pahat putar (rotary tool) dan pendingin udara (air cooling), ”Jurusan Teknik Mesin, Universitas Lampung. Bandar Lampung.

[9] Mohanty, Tanmaya, "Study of chip reduction coefficient in boring operation using metals laminate at the tool-holder interface," International Jurnal of Innovative Research in Science Engineering and Technology, Vol. 3, Issue 10, India, 2014.

[10] Lepar, Samuel, "Analisis rasio ketebalan geram pada proses pembubutan," Tugas Akhir, Universitas Samratulangi. Manado.

[11] C. Gao and L. Zhang, "Effect of cutting conditions on the seratted chip formation in high speed cutting," Machining Science and Technology, Vol. 17, pp 26-40, 2013. 
[12] D. Arifian, “Analisa keausan pahat putar pada pembubutan magnesium az31 menggunakan udara dingin bertekanan," Tugas Akhir, Universitas Lampung. Lampung, 2017.

[13] F. Fariza, "Evaluasi dan analisa kinerja sistem pahat putar modular untuk pemesinan peralatan kesehatan ortopedi berbasis material titanium 6AL-4V ELI," Laporan Tugas Akhir, Universitas Lampung, 2017. 